\title{
Analysis of Genetic Variability for Quantitative Traits in Chilli Germplasm
}

\author{
P. Pandiyaraj ${ }^{1 *}$, V. Lakshmanan ${ }^{2}$, D. Saraladevi ${ }^{2}$ and S. Juliet Hepziba ${ }^{2}$ \\ ${ }^{1}$ Division of Vegetable Crops, Indian Institute of Horticultural Research, \\ Bengaluru - 560 089, Karnataka, India \\ ${ }^{2}$ Department of Vegetable Crops, Horticulture College and Research Institute, \\ Periyakulam - 625 601, Tamil Nadu, India \\ *Corresponding author
}

\section{A B S T R A C T}

Field experiments were conducted at Horticulture College and Research Institute, Tamil

Keywords

Chilli, Germplasm, Quantitative traits, PCV, GCV, Hertiability, GA.

Article Info

Accepted:

12 October 2017

Available Online:

10 December 2017
Nadu Agricultural University, Periyakulam during August, 2013 to April, 2014. The experiment was conducted in a randomized block design with two replication. Thirty three germplasm seeds are collected from the NBPGR, Regional station, Rajendranagar, Hyderabad. The data were observed from five randomly selected competitive plants from each replication for twelve quantitative traits. Analysis of variance revealed the significance differences among the genotypes. The phenotypic coefficient of variation was higher than genotypic coefficient of variation for all characters indicating the influence of environment on these characters. High phenotypic and genotypic coefficient of variation was observed for all the characters except days to first flowering and number of seeds per pod. High heritability was observed for all character except number of secondary branches per plant, dry pod yield per plant and days to first flowering. High genetic advance as per cent of mean was observed for all character except days to first flowering and number of secondary branches per plant.

\section{Introduction}

Chilli is an important vegetable as well as spice crop grown in the tropical and subtropical areas of the world. In India chilli is an important commodity used as a vegetable, spice, medicinal herb and ornamental plant. It is also used as an ingredient in industrial products. Crop improvement largely depends on existence of genetic variability. Improvement in any crop is based on the extent of genetic variation present in it and, the degree of improvement depends on magnitude of the available, beneficial genetic variability. The plant breeder has to identify the sources of favourable genes, incorporate them in breeding populations and aim for isolation of productive genotypes and cultivars. Thus, improvement in any crop is based on the extent of genetic variation and the degree of improvement depends upon the magnitude of available beneficial genetic variability.

Since, yield is a complex trait, governed by a large number of component traits, it is imperative to know the interrelationship between yield and its component traits to arrive at an optimal selection index for improvement of yield. Yield is a quantitative 
trait that is influenced by a number of yield contributing parameters. The selection of desirable genotypes is usually based on yield and yield components. It is therefore necessary to study the mutual relationship between yield and yield components for efficient utilization of the genetic stock in crop improvement program of chilli. Variability in plants is the first step in understanding how to improve or produce new plants. Heritability is the degree of genetic control associated to some important traits (Addissu, 2012). It indicates how much of the genetic variability has a genetic origin and gives necessary information for the genetic selection process (Falconer, 1981). To improve yield potentials of crops in any breeding programs, it is necessary to obtain adequate information on the magnitude and type of genetic variability and their corresponding heritability. This is because selection of superior genotypes is proportional to the amount of genetic variability present and the extent to which the characters are inherited. Heritability is used to indicate the relative degree to which a character is transmitted from parent to offspring. The magnitude of such estimates also suggests the extent to which improvement is possible through selection (Nechif et al., 2011).

\section{Materials and Methods}

The experiment was conducted in a randomized block design with two replication. Thirty three germplasm seeds are collected from the NBPGR, Regional station, Rajendranagar, Hyderabad were sown in the nursery and forty five days old seedlings were transplanted in ridges and furrow, at a spacing of $45 \times 45 \mathrm{~cm}$. Three ridges were maintained for each genotype and each replication. Standard horticultural practices (TNAU crop production guide) and plant protection measures were adapted uniformly to all the genotypes. The parameters considered for the study were plant height, number of primary branches per plant, number of secondary branches per plant, days to first flowering, number of pods per plant, pod length, pod girth, mean pod weight, red pod yield per plant, dry pod yield per plant, number of seed per pod, thousand seed weight. Analysis of variance (Panse and Sukhatme, 1967), genotypic and phenotypic coefficient of variation (Burton and Devane, 1953), heritability in broad sense (Hanson et al., 1956) and expected genetic advance (Johnson et al., 1955) were estimated for all the characters. Correlation coefficients for all quality parameters (Al-Jibouri et al., 1958) were also estimated.

\section{Results and Discussion}

Analysis of variance showed significant differences among the genotypes for all the twelve quantitative parameters, indicating the sufficient genetic variability to be exploited in breeding programme (Table 1). Similar results were noticed by Vani et al., (2007); Krishnamurthy et al., (2013). The extent of variability with respect to twelve quantitative characters in thirty three germplasm measured in term of mean performance, phenotypic coefficient of variation (PCV), genotypic coefficient of variation (GCV), heritability, genetic advance as percent of mean are given in Table 2. The rang of variation was high for red pod yield per plant (101.86-488.26 g) followed by number of pod per plant (47.40207.70), number of seeds per pod (56.1099.60), plant height $(37.29-100.30 \mathrm{~cm})$, days to first flowering (57.10-77.20 days), dry pod yield per plant (20.72-93.99 g) and number of secondary branches per plant (11.90-24.50).

Relatively low range of variability was recorded in respect to number of primary braches per plant (4.50-8.70), pod length $(2.90-10.41 \mathrm{~cm})$, thousand seed weight $(2.87$ $4.96 \mathrm{~g})$, pod girth $(1.59-4.00 \mathrm{~cm})$ and mean pod 
weight (0.25-0.92 gm) and these finding are in accordance with Krishna et al., (2007); Chakravorty and Maity (2010).

The phenotypic coefficient of variation (PCV) was higher than the genotypic coefficient of variation $(\mathrm{GCV})$ for all the characters (Table 2) and the difference between PCV and GCV was narrow indicating the little influence of environment on the expression of these characters and considerable amount of variation was observed for all the characters. These results are supported by earlier observations of Krishnamurthy et al., (2013); Munshi et al., (2010); Sandeep et al., (2013). The estimates of PCV and GCV were recorded high for red pod yield per plant (38.549 and $38.527 \%$ ), dry pod yield per plant (36.03 and $35.73 \%$ ), mean pod weight (33.44 and $32.66 \%$ ), number of pods per plant (31.99 and $31.930 \%)$ and pod length (30.41 and $30.29 \%)$ indicating higher magnitude of variability for these characters. Similar results were also reported by Singh and Singh (2011) for average dry fruit weight, Cheema et al., (2010); Sharma et al., (2011) for fruit yield per plant, Kumar et al., (2012) for yield per plant and Rajyalakshmi and Vijayapadma (2012) for number of fruits per plant. The estimates of PCV and GCV were moderate for pod girth (21.41 and 18.60), plant height (17.27 and 17.142), number of secondary branches per plant (17.21 and 11.96), thousand seed weight (16.83 and 15.02 ), number of primary branches per plant (15.81 and 14.95) and number of seeds per pod (12.92 and 12.44). Similar observations were earlier reported by Warshamana et al., (2008) for fruit girth and Nehru et al., (2012) for plant height.

Table.1 Analysis of variance for quantitative characters in chilli germplasm

\begin{tabular}{|l|l|c|c|c|}
\hline S.No & Characters & Replication & Genotypes & Error \\
\hline 1. & Plant height $(\mathrm{cm})$ & 90.0009 & 362.762 & 2.693 \\
\hline 2. & Number of primary branches per plant & 0.0009 & 1.9501 & 0.1081 \\
\hline 3. & Number of primary braches per plant & 8.4386 & 13.2438 & 4.6189 \\
\hline 4. & Days to first flowering & 38.1193 & 35.3076 & 2538.2109 \\
\hline 5. & Number of pods per plant & 13.0341 & 2538.2109 & 5.1376 \\
\hline 6. & Pod length (cm) & 0.1266 & 5.5097 & 0.0203 \\
\hline 7. & Pod girth (cm) & 0.0649 & 0.4980 & 0.0696 \\
\hline 8. & Mean pod weight (gm) & 0.0046 & 0.0488 & 0.0011 \\
\hline 9. & Number of seeds per pod & 34.661 & 239.6563 & 9.0731 \\
\hline 10. & Thousand seed weight $(\mathrm{gm})$ & 0.3867 & 0.7582 & 0.0857 \\
\hline 11. & Red pod yield per plant $(\mathrm{gm})$ & 2481.678 & 424.748 & 1.7523 \\
\hline 12. & Dry pod yield per plant $(\mathrm{gm})$ & 0.2485 & 0.2485 & 0.0219 \\
\hline
\end{tabular}


Table.2 Estimation of mean, range, components of variance, heritability and genetic advance for chilli germplasm

\begin{tabular}{|c|c|c|c|c|c|c|c|c|}
\hline \multirow[t]{2}{*}{ S.No } & \multirow[t]{2}{*}{ Characters } & \multicolumn{2}{|c|}{ Range } & \multirow[t]{2}{*}{ Mean } & \multirow[t]{2}{*}{$\mathbf{P C V}$} & \multirow[t]{2}{*}{ GCV } & \multirow{2}{*}{$\begin{array}{c}\text { Heritability } \\
(\%)\end{array}$} & \multirow{2}{*}{$\begin{array}{c}\text { GA as per } \\
\text { cent of mean }\end{array}$} \\
\hline & & Maximum & Minimum & & & & & \\
\hline 1. & Plant height $(\mathrm{cm})$ & 100.3 & 37.29 & 78.27 & 17.27 & 17.142 & 98.5 & 35.052 \\
\hline 2. & Number of primary branches per plant & 8.7 & 4.5 & 6.41 & 15.813 & 14.959 & 89.5 & 29.154 \\
\hline 3. & Number of secondary branches per plant & 24.5 & 11.9 & 17.35 & 17.217 & 11.964 & 48.2 & 17.125 \\
\hline 4. & Days to first flowering & 77.2 & 57.1 & 64.75 & 7.321 & 5.532 & 57.1 & 8.611 \\
\hline 5. & Number of pods per plant & 207.7 & 47.4 & 111.45 & 31.995 & 31.93 & 99.6 & 65.644 \\
\hline 6. & Pod length $(\mathrm{cm})$ & 10.41 & 2.9 & 5.46 & 30.41 & 30.298 & 99.2 & 62.185 \\
\hline 7. & Pod girth $(\mathrm{cm})$ & 4 & 1.59 & 2.48 & 21.414 & 18.602 & 75.4 & 33.29 \\
\hline 8. & Mean pod weight (gm) & 0.92 & 0.25 & 0.47 & 33.446 & 32.667 & 95.4 & 65.73 \\
\hline 9. & Number of seeds per pod & 99.6 & 56.1 & 86.26 & 12.927 & 12.447 & 92.7 & 24.688 \\
\hline 10. & Thousand seed weight (gm) & 4.96 & 2.87 & 3.85 & 16.833 & 15.027 & 79.6 & 27.635 \\
\hline 11. & Red pod yield per plant (gm) & 488.26 & 101.86 & 232.24 & 15.212 & 15.15 & 99.1 & 31.081 \\
\hline 12. & Dry pod yield per plant (gm) & 93.99 & 20.72 & 60.61 & 33.715 & 24.067 & 50.9 & 35.392 \\
\hline
\end{tabular}


Heritability estimates along with genetic advance would be helpful in predicted the gain under selection than heritability estimates alone. Burton and Devane (1953) suggested that genotypic coefficient of variation together with heritability estimates would give the best picture of the extent of genetic advance expected by selection. In the present investigation, high heritability coupled with high genetic advance observed for characters like red pod yield per plant, dry pod yield per plant, mean pod weight, mean pod weight, number of pods per plant, pod length, plant height, pod girth, number of primary branches per plant, thousand seed weight and number of seeds per fruit revealed the role of additive gene action in the expression of these characters. Thus, these characters could be considered as the reliable indices for selection. Similar results of high heritability and high genetic advance by Jabeen et al., (1998); Bharadwaj et al., (2007) in chilli lend credence to the present findings. On the basis of the present study, it could be concluded that simultaneous selection based on multiple characters having high estimates of heritability and genetic advance could be exercised for improvement through selection.

\section{References}

Addissu A G. 2012. Heritability and genetic advance in recombinant inbred lines for drought tolerance and other related traits in sorghum (Sorghum bicolor). Continental Journal Agricultural Science 5: 1-9.

Al-Jibouri H A, Miller P A and Robinson H V. 1958. Genotypic and environmental variances and co-variances in a upland cotton cross of interspecific origin. Agronomy Journal 50: 633-536.

Burton G W and Devane E H. 1953. Estimating the heritability in tall fescue (Festuca arundinancea) from replicated clonal material. Agronomy Journal 45:
478-481.

Cheema, D S, Jindal S K and Dhaliwal M S. 2010. Evaluation of chilli hybrids developed by using genetic male sterility. Haryana Journal of Horticultural Sciences 39(3 \& 4): 321325.

Falconer D. S. 1981. Introduction to Quantitative Genetics, Longman

Farhad M, Hasanuzzaman M, Biswas B K, Azad A K and Arifuzzaman M. 2008. Reliability of yield contributing characters for improving yield potential in chilli (Capsicum annuum L). International J. Sustainable Crop Production 3(3): 30-38.

Hanson G H, Robinson H F and Comstock R E. 1956. Biometrical studies of yield in segregating population of Korean Lespedeza. Agronomy Journal 48: 268272.

Jabeen, N., Ahmad, N. and Tanki, M.I. 1998. Genetic variability in hot pepper (Capsicum annuum L.). Agricultural Science Digest. 18: 23-26

Johnson H W, Robinson H F and Comstock R E. 1955. Estimates of genetic and environmental variability in soyabean. Agronomy Journal 47: 314-318.

Kumar D, Bahadur V, Rangare S B and Singh D. 2012. Genetic variability, heritability and correlation studies in chilli (Capsicum annuum L.). Horti Flora Research Spectrum 1: 248-252.

Lush J L. 1940. Intra-sire correlations or regressions of offspring on dam as method of estimating heritability of characteristics. $33^{\text {rd }}$ Annual proceeding of American society animal production. P.293

Manju P R and Sreelathakumary I. 2002. Genetic variability, heritability and genetic advance in hot chilli (Capsicum chinense). Journal of Tropical Agriculture 40: 4-6.

Munshi A D and Behera T K. 2000. Genetic 
variability, heritability and genetic advance for some traits in chillies (Capsicum annuиm L.). Vegetable Science 27: 39-41.

Munshi A D, Kumar B K, Sureja A K and Joshi S. 2010. Genetic variability, heritability and genetic advance for growth, yield and quality traits in chilli. Indian Journal of Horticulture 67: 114116.

Naresh P, Madhavi reddy K, Shivashankara K S and George Christopher M. 2013. Genetic variation for biochemical compounds in capsicum. Indian Journal of Horticulture 70(1): 43-47.

Nechif O, Filimon R and Szilagyi L. 2011. Genetic variability, heritability and expected genetic advance as indices for yield and yield components selection in common bean (Phaseolus vulgaris L.). Scientific Papers, UASVM Bucharest, Series A 1222-5339,

Nehru S D, Thimmegowda M N and Gowda M. 2012. Growth, yield, genetic variability and correlation studies in chilli (Capsicum annum L.). Research Journal of Agricultural Sciences 3(2): 517-519.
Panse V G and Sukhatme P V. 1967. Statistical Methods for Agricultural Workers. Indian Council of Agricultural Research, New Delhi, p. 21.

Rajyalakshmi and Vijayapadma. 2012. Studies on performance, genetic variability, heritability and genetic advances in chilli (Capsicum annuum L.) varieties in high altitude and tribal zone of Srikakulam district of Andhra pradesh, India. Plant Archives 12: 717 720.

Robinson H F, Comstock R E and Harvey P H. 1949. Estimates of heritability and degree of dominance in corn. Agronomy Journal 41: 253-259.

Sandeep, Somanath A and Mohan Kumar H D. 2013. Genetic variability, heritability and genetic advance for yield and its components in Byadgi Kaddi chilli (Capsicum annuит L.) accessions. Bioinfolet 10(1A): 50-53.

Vani, S.K., Sridevi, O. and Salimath, P.M. 2007. Studies on genetic variability, correlation and path analysis in chilli (Capsicum annuum L.). Annuals of Biology. 23: 117-121.

\section{How to cite this article:}

Pandiyaraj, P., V. Lakshmanan, D. Saraladevi and Juliet Hepziba, S. 2017. Analysis of Genetic Variability for Quantitative Traits in Chilli Germplasm. Int.J.Curr.Microbiol.App.Sci. 6(12): 1648-1653. doi: https://doi.org/10.20546/ijcmas.2017.612.185 